\title{
Nanotechnology, bionanotechnology and microbial cell factories
}

\author{
Antonio Villaverde $1,2,3$
}

\begin{abstract}
Nanotechnology is increasingly using both materials and nano-objects synthesized by living beings, most of them produced by microbial cells. Emerging technologies and highly integrative approaches (such as 'omics and systems biology), that have been largely proven successful for the production of proteins and secondary metabolites are now expected to become fully adapted for the improved biological production of nanostructured materials with tailored properties. The so far underestimated potential of microbial cell factories in nanotechnology and nanomedicine is expected to emerge, in the next years, in the context of novel needs envisaged in the nanoscience universe. This should prompt a careful revisiting of the microbial cell factories as the most versatile biological platforms to supply functional materials for nanotechnological applications.
\end{abstract}

Generally speaking, Nanotechnology refers to the fabrication, manipulation and utilization of submicron objects, particularly those between 1 and $100 \mathrm{~nm}$. Physical and chemical sciences have developed tools and procedures to fabricate nanoscale entities with intriguing applications in electronics, material sciences and medicine. In the biomedical context, the relevance of Nanotechnology relies on the particular biophysical properties of nanoscale objects and their particular interaction with living beings such as high diffusion in organs and tissues, high surface-volume ratio, efficient uptake by mammalian cells and high biological impact in biological interfaces through mecano-transduction signaling [1] and a spectrum of alternative cell activities and responses [2]. The extraordinary bio-effectiveness of nanoparticles has in turn derived into a strong debate about their potential toxicity, when directly exposed to the human body or released to the environment [3], which is still unsolved. The biological impact of these manmade nanoscale entities and their suitability to be functionalized for specific binding or to act as carriers for therapeutics empowers a spectrum of specific applications in diagnosis and therapy, including imaging, biosensing, regenerative medicine, drug delivery and gene therapy. The clinically-oriented fabrication, tailoring and

Correspondence: antoni.villaverde@uab.cat

${ }^{1}$ Institute for Biotechnology and Biomedicine, Universitat Autònoma de Barcelona, Bellaterra, 08193 Barcelona, Spain application of bio-active nanoparticles conceptually sustains the Nanomedicine framework.

Bionanotechnology (as well as Nanobiotechnolgy) are rather fuzzy terms whose overlapping meanings are under continuous refining, as their associated technologies and applications keep evolving. They are often understood as the generation of hybrid materials (deriving from chemical and biological synthesis), or bioinspired materials [4]. In a different reading frame, Bionanotechnology can be observed as "Nanotechnology through Biotechnology" [5], that is, the bio-fabrication of nano-objects, or bi-functional macromolecules usable as tools to construct or manipulate nano-objects. Because of their wide physiological diversity, small size, genetic manipulability and controlled culturability, microbial cells are ideal producers of a diversity of nanostructures, materials and instruments for Nanosciences, ranging from fully natural products such as viruses, polymers and magnetosomes, to engineered proteins or protein constructs such as virus-like particles (VLPs), and peptide-displaying phages or cells and tailored metal particles (Figure 1).

In summary, microbial cells are natural producers of (or they can be easily adapted to synthesize) nano-sized entities with relevant biomedical applications, being the cell factories themselves promising tools for the emerging technologies and biomedical applications related with the use of nanosized entities. Microbial Call Factories, the journal, has addressed some of these relevant 


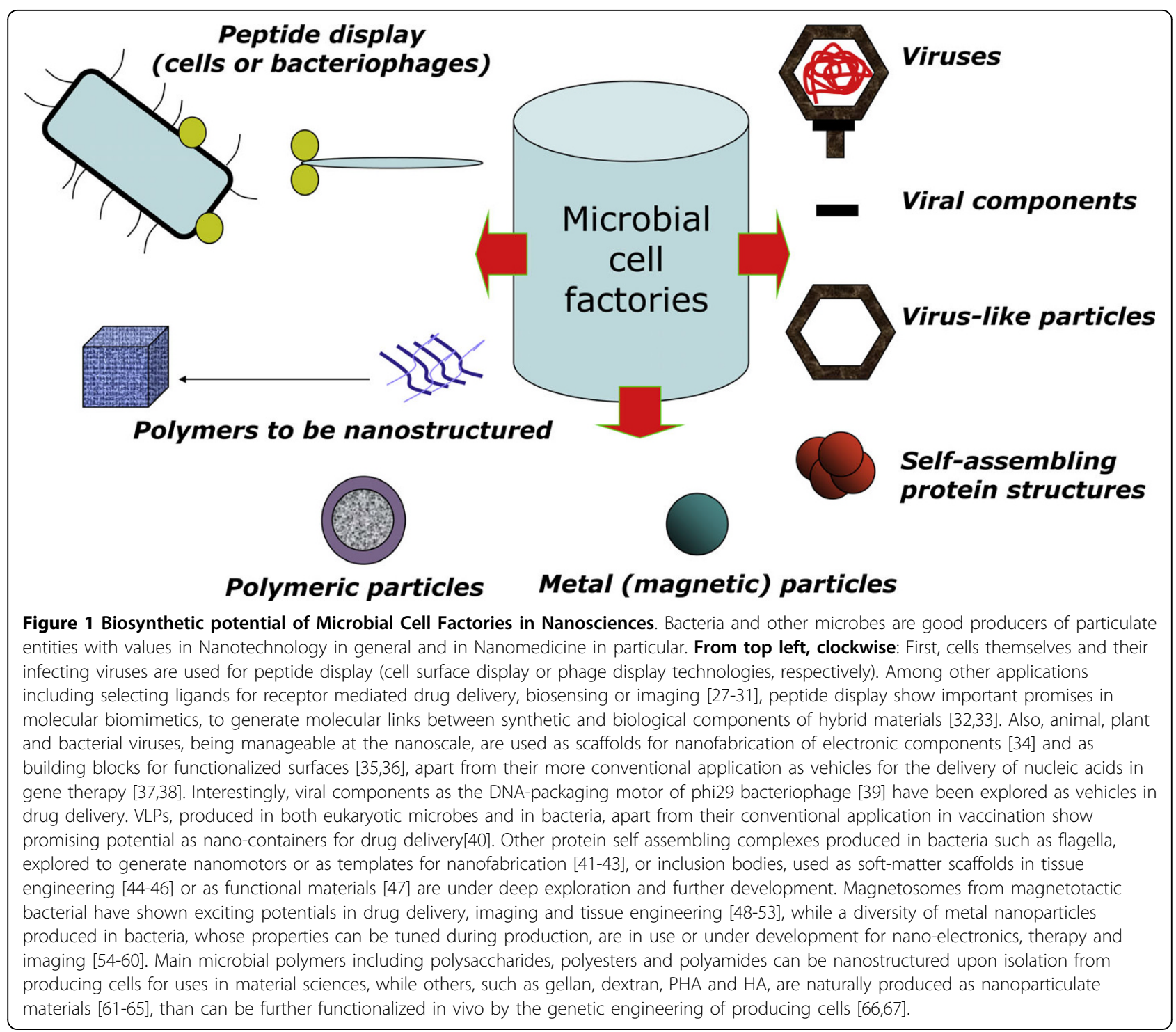

topics through primary research papers and reviews. For instance, Chen and coauthors [6] have recently shown how polyhydroxyalkanoate (PHA) nanosized granules are convenient instruments for protein purification, while other authors [7] have improved the production of clinically relevant microbial materials suitable for nanoparticle in vitro fabrication including alginate, hyaluronic acid (HA) and PHA $[8,9]$.

Moreover, cell surface display technologies $[10,11]$ as well as the engineering of bacterial particulate materials (such as spores) for peptide display [12] have been represented in our article list. Furthermore, the journal has often addressed protein quality issues [13-19], that are highly relevant to the design and production of protein complexes and protein nanoparticles, among which virus like particles (VLPs) [20], self-assembling silk-like proteins [21] and bacterial inclusion bodies [22-26] have been particularly studied.

However, the number of submissions dealing with Nanotechnological applications or instruments deriving from microbial cells and the spectrum of coverage of Nanoscience-related topics are still low. Therefore, the editorial board of Microbial Cell Factories is pleased to encourage all the authors working in microbiology, biomedicine and biomaterial sciences to consider the potential of the Cell Factory platforms and to submit their primary research data and reviews to the journal. As a fully settled but highly dynamic journal, Microbial Cell Factories is committed to fully cover emerging technologies and scientific areas of hot interest from which microbial products are relevant, provided the biological aspects of the production (the Cell Factory 
concept) of the model particles, structures or materials are conveniently stressed.

\author{
Author details \\ ${ }^{1}$ Institute for Biotechnology and Biomedicine, Universitat Autònoma de \\ Barcelona, Bellaterra, 08193 Barcelona, Spain. ${ }^{2}$ Department of Genetics and \\ Microbiology, Universitat Autònoma de Barcelona, Bellaterra, 08193 \\ Barcelona, Spain. ${ }^{3} \mathrm{CIBER}$ de Bioingeniería, Biomateriales y Nanomedicina \\ (CIBER-BBN), Bellaterra, 08193 Barcelona, Spain.
}

Received: 27 June 2010 Accepted: 5 July 2010 Published: 5 July 2010

\section{References}

1. Curtis AS, Dalby M, Gadegaard N: Cell signaling arising from nanotopography: implications for nanomedical devices. Nanomed 2006, 1:67-72.

2. Jiang W, Kim BY, Rutka JT, Chan WC: Nanoparticle-mediated cellular response is size-dependent. Nat Nanotechnol 2008, 3:145-150.

3. Sanvicens N, Marco MP: Multifunctional nanoparticles-properties and prospects for their use in human medicine. Trends Biotechnol 2008, 26:425-433.

4. Taylor PM: Biological matrices and bionanotechnology. Philos Trans $R$ Soc Lond B Biol Sci 2007, 362:1313-1320.

5. Sarikaya M, Tamerler C, Jen AK, Schulten K, Baneyx F: Molecular biomimetics: nanotechnology through biology. Nat Mater 2003, 2:577-585.

6. Zhang S, Wang ZH, Chen GQ: Microbial polyhydroxyalkanote synthesis repression protein PhaR as an affinity tag for recombinant protein purification. Microb Cell Fact 2010, 9:28.

7. Vazquez JA, Montemayor MI, Fraguas J, Murado MA: Hyaluronic acid production by Streptococcus zooepidemicus in marine by-products media from mussel processing wastewaters and tuna peptone viscera. Microb Cell Fact 2010, 9:46.

8. Singh M, Patel SK, Kalia VC: Bacillus subtilis as potential producer for polyhydroxyalkanoates. Microb Cell Fact 2009, 8:38.

9. Galindo E, Pena C, Nunez C, Segura D, Espin G: Molecular and bioengineering strategies to improve alginate and polydydroxyalkanoate production by Azotobacter vinelandii. Microb Cell Fact 2007, 6:7.

10. Shao X, Jiang M, Yu Z, Cai H, Li L: Surface display of heterologous proteins in Bacillus thuringiensis using a peptidoglycan hydrolase anchor. Microb Cell Fact 2009, 8:48.

11. Rutherford N, Mourez M: Surface display of proteins by gram-negative bacterial autotransporters. Microb Cell Fact 2006, 5:22.

12. Hinc K, Isticato R, Dembek M, Karczewska J, Iwanicki A, Peszynska-Sularz G, et al: Expression and display of UreA of Helicobacter acinonychis on the surface of Bacillus subtilis spores. Microb Cell Fact 2010, 9:2.

13. Martinez-Alonso M, Gonzalez-Montalban N, Garcia-Fruitos E, Villaverde A: Learning about protein solubility from bacterial inclusion bodies. Microb Cell Fact 2009, 8:4.

14. Garcia-Fruitos E, Gonzalez-Montalban N, Morell M, Vera A, Ferraz RM, Aris A, et al: Aggregation as bacterial inclusion bodies does not imply inactivation of enzymes and fluorescent proteins. Microb Cell Fact 2005, 4:27.

15. de Marco A: Strategies for successful recombinant expression of disulfide bond-dependent proteins in Escherichia coli. Microb Cell Fact 2009, 8:26.

16. Kolaj O, Spada S, Robin S, Wall JG: Use of folding modulators to improve heterologous protein production in Escherichia coli. Microb Cell Fact 2009, $8: 9$

17. Sorensen HP, Mortensen KK: Soluble expression of recombinant proteins in the cytoplasm of Escherichia coli. Microb Cell Fact 2005, 4:1.

18. Ferrer-Miralles N, Domingo-Espin J, Corchero JL, Vazquez E, Villaverde A: Microbial factories for recombinant pharmaceuticals. Microb Cell Fact 2009, 8:17

19. Gasser B, Saloheimo M, Rinas U, Dragosits M, Rodriguez-Carmona E, Baumann K, et al: Protein folding and conformational stress in microbial cells producing recombinant proteins: a host comparative overview. Microb Cell Fact 2008, 7:11.

20. Gurramkonda C, Adnan A, Gabel T, Lunsdorf H, Ross A, Nemani SK, et al: Simple high-cell density fed-batch technique for high-level recombinant protein production with Pichia pastoris: Application to intracellular production of Hepatitis B surface antigen. Microb Cell Fact 2009, 8:13.

21. Scheibel T: Spider silks: recombinant synthesis, assembly, spinning, and engineering of synthetic proteins. Microb Cell Fact 2004, 3:14.

22. Peternel S, Grdadolnik J, Gaberc-Porekar V, Komel R: Engineering inclusion bodies for non denaturing extraction of functional proteins. Microb Cell Fact 2008, 7:34.

23. Sabate R, Espargaro A, Saupe SJ, Ventura S: Characterization of the amyloid bacterial inclusion bodies of the HET-s fungal prion. Microb Cell Fact 2009, 8:56.

24. Parrilli $E$, Giuliani M, Marino G, Tutino ML: Influence of production process design on inclusion bodies protein: the case of an Antarctic flavohemoglobin. Microb Cell Fact 2010, 9:19.

25. Jurgen B, Breitenstein A, Urlacher V, Buttner K, Lin H, Hecker M, et al: Quality control of inclusion bodies in Escherichia coli. Microb Cell Fact 2010, 9:41.

26. Lethanh $H$, Neubauer $P$, Hoffmann F: The small heat-shock proteins IbpA and $\mathrm{IbpB}$ reduce the stress load of recombinant Escherichia coli and delay degradation of inclusion bodies. Microb Cell Fact 2005, 4:6.

27. Petty NK, Evans TJ, Fineran PC, Salmond GP: Biotechnological exploitation of bacteriophage research. Trends Biotechnol 2007, 25:7-15.

28. Deutscher SL: Phage display in molecular imaging and diagnosis of cancer. Chem Rev 2010, 110:3196-3211.

29. Balestrieri ML, Napoli C: Novel challenges in exploring peptide ligands and corresponding tissue-specific endothelial receptors. Eur J Cancer 2007, 43:1242-1250.

30. Aina OH, Liu R, Sutcliffe JL, Marik J, Pan CX, Lam KS: From combinatorial chemistry to cancer-targeting peptides. Mol Pharm 2007, 4:631-651.

31. Sidhu SS: Phage display in pharmaceutical biotechnology. Curr Opin Biotechnol 2000, 11:610-616.

32. Sarikaya M, Tamerler C, Jen AK, Schulten K, Baneyx F: Molecular biomimetics: nanotechnology through biology. Nat Mater 2003, 2:577-585.

33. Tamerler C, Sarikaya M: Molecular biomimetics: nanotechnology and bionanotechnology using genetically engineered peptides. Philosophical Transactions of the Royal Society A-Mathematical Physical and Engineering Sciences 2009, 367:1705-1726.

34. Mao C, Solis DJ, Reiss BD, Kottmann ST, Sweeney RY, Hayhurst A, et al: Virus-based toolkit for the directed synthesis of magnetic and semiconducting nanowires. Science 2004, 303:213-217.

35. Steinmetz NF, Bize A, Findlay KC, Lomonossoff GP, Manchester M, Evans DJ, et al: Site-specific and Spatially Controlled Addressability of a New Viral Nanobuilding Block: Sulfolobus islandicus Rod-shaped Virus 2. Advanced Functional Materials 2008, 18:3478-3486.

36. Steinmetz NF, Shah SN, Barclay JE, Rallapalli G, Lomonossoff GP, Evans DJ: Virus-templated silica nanoparticles. Small 2009, 5:813-816.

37. Edelstein ML, Abedi MR, Wixon J: Gene therapy clinical trials worldwide to 2007-an update. J Gene Med 2007, 9:833-842.

38. Evans DJ: Exploitation of plant and archaeal viruses in bionanotechnology. Biochem Soc Trans 2009, 37:665-670.

39. Lee TJ, Schwartz C, Guo P: Construction of bacteriophage phi29 DNA packaging motor and its applications in nanotechnology and therapy. Ann Biomed Eng 2009, 37:2064-2081.

40. Bundy BC, Franciszkowicz MJ, Swartz JR: Escherichia coli-based cell-free synthesis of virus-like particles. Biotechnol Bioeng 2008, 100:28-37.

41. Martel S, Felfoul O, Mohammadi M, Mathieu JB: Interventional procedure based on nanorobots propelled and steered by flagellated magnetotactic bacteria for direct targeting of tumors in the human body. Conf Proc IEEE Eng Med Biol Soc 2008, 2008:2497-2500.

42. Deplanche K, Woods RD, Mikheenko IP, Sockett RE, Macaskie LE: Manufacture of stable palladium and gold nanoparticles on native and genetically engineered flagella scaffolds. Biotechnol Bioeng 2008, 101:873-880.

43. van den Heuvel MG, Dekker C: Motor proteins at work for nanotechnology. Science 2007, 317:333-336.

44. Garcia-Fruitos E, Seras-Franzoso J, Vazquez E, Villaverde A: Tunable geometry of bacterial inclusion bodies as substrate materials for tissue engineering. Nanotechnology 2010, 21:205101.

45. Diez-Gil C, Krabbenborg S, Garcia-Fruitos E, Vazquez E, RodriguezCarmona $\mathrm{E}$, Ratera I, et al: The nanoscale properties of bacterial inclusion bodies and their effect on mammalian cell proliferation. Biomaterials 2010, 31:5805-5812. 
46. Garcia-Fruitos E, Rodriguez-Carmona E, Diez-Gil C, Ferraz RM, Vazquez E, Corchero JL, et al: Surface Cell Growth Engineering Assisted by a Novel Bacterial Nanomaterial. Advanced Materials 2009, 21:4249-4253.

47. Garcia-Fruitos E, Villaverde A: Friendly production of bacterial inclusion bodies. Korean Journal of Chemical Engineering 2010, 27:385-389.

48. Corchero JL, Villaverde A: Biomedical applications of distally controlled magnetic nanoparticles. Trends Biotechnol 2009, 27:468-476.

49. Ding Y, Li J, Liu J, Yang J, Jiang W, Tian J, et al: Deletion of the ftsZ-like gene results in the production of superparamagnetic magnetite magnetosomes in Magnetospirillum gryphiswaldense. J Bacteriol 2010, 192:1097-1105.

50. Ohuchi S, Schuler D: In vivo display of a multisubunit enzyme complex on biogenic magnetic nanoparticles. Appl Environ Microbiol 2009, 75:7734-7738.

51. Sun JB, Duan JH, Dai SL, Ren J, Guo L, Jiang W, et al: Preparation and antitumor efficiency evaluation of doxorubicin-loaded bacterial magnetosomes: magnetic nanoparticles as drug carriers isolated from Magnetospirillum gryphiswaldense. Biotechnol Bioeng 2008, 101:1313-1320.

52. Sun JB, Zhao F, Tang T, Jiang W, Tian JS, Li Y, et al: High-yield growth and magnetosome formation by Magnetospirillum gryphiswaldense MSR-1 in an oxygen-controlled fermentor supplied solely with air. Appl Microbiol Biotechnol 2008, 79:389-397.

53. Lang C, Schuler D, Faivre D: Synthesis of Magnetite Nanoparticles for Bioand Nanotechnology: Genetic Engineering and Biomimetics of Bacterial Magnetosomes. Macromol Biosci 2007, 7:144-151.

54. Vaidyanathan R, Gopalram S, Kalishwaralal K, Deepak V, Pandian SR, Gurunathan S: Enhanced silver nanoparticle synthesis by optimization of nitrate reductase activity. Colloids Surf B Biointerfaces 2010, 75:335-341.

55. Gurunathan S, Kalishwaralal K, Vaidyanathan R, Venkataraman D, Pandian SR, Muniyandi J, et al: Biosynthesis, purification and characterization of silver nanoparticles using Escherichia coli. Colloids Surf B Biointerfaces 2009, 74:328-335

56. Chen YL, Tuan HY, Tien CW, Lo WH, Liang HC, Hu YC: Augmented biosynthesis of cadmium sulfide nanoparticles by genetically engineered Escherichia coli. Biotechnol Prog 2009, 25:1260-1266.

57. Kalishwaralal K, Deepak V, Pandian SRK, Gurunathan S: Biological synthesis of gold nanocubes from Bacillus licheniformis. Bioresource Technology 2009, 100:5356-5358.

58. Kalimuthu K, Suresh BR, Venkataraman D, Bilal M, Gurunathan S: Biosynthesis of silver nanocrystals by Bacillus licheniformis. Colloids Surf $B$ Biointerfaces 2008, 65:150-153.

59. Husseiny MI, El-Aziz MA, Badr Y, Mahmoud MA: Biosynthesis of gold nanoparticles using Pseudomonas aeruginosa. Spectrochim Acta A Mol Biomol Spectrosc 2007, 67:1003-1006.

60. Gericke M, Pinches A: Microbial production of gold nanoparticles. Gold Bulletin 2006, 39:22-28.

61. Chen CQ: A microbial polyhydroxyalkanoates (PHA) based bio- and materials industry. Chem Soc Rev 2009, 38(8):2434-2446, Ref Type: Generic.

62. Atwood JA, Rehm BH: Protein engineering towards biotechnological production of bifunctional polyester beads. Biotechnol Lett 2009, 31:131-137.

63. Ossipov DA: Nanostructured hyaluronic acid-based materials for active delivery to cancer. Expert Opin Drug Deliv 2010, 7(6):681-703.

64. Ibrahim HK, El-Leithy IS, Makky AA: Mucoadhesive Nanoparticles as Carrier Systems for Prolonged Ocular Delivery of Gatifloxacin/Prednisolone Bitherapy. Mol Pharm 2010, 7:576-585.

65. Mellors R, Benzeval I, Eisenthal R, Hubble J: Preparation of self-assembled microspheres and their potential for drug delivery. Pharmaceutical Development and Technology 2010, 15:105-111.

66. Yao YC, Zhan XY, Zhang J, Zou XH, Wang ZH, Xiong YC, et al: A specific drug targeting system based on polyhydroxyalkanoate granule binding protein PhaP fused with targeted cell ligands. Biomaterials 2008, 29:4823-4830.

67. Grage K, Jahns AC, Parlane N, Palanisamy R, Rasiah IA, Atwood JA, et al: Bacterial Polyhydroxyalkanoate Granules: Biogenesis, Structure, and Potential Use as Nano-/Micro-Beads in Biotechnological and Biomedical Applications. Biomacromolecules 2009, 10:660-669.

doi:10.1186/1475-2859-9-53

Cite this article as: Villaverde: Nanotechnology, bionanotechnology and microbial cell factories. Microbial Cell Factories 2010 9:53.

\section{Submit your next manuscript to BioMed Central and take full advantage of:}

- Convenient online submission

- Thorough peer review

- No space constraints or color figure charges

- Immediate publication on acceptance

- Inclusion in PubMed, CAS, Scopus and Google Scholar

- Research which is freely available for redistribution 